Dragomir Bondžić

\title{
The Repercussions of the Tito-Stalin Split in 1948 on the University of Belgrade
}

After the Second World War, the University of Belgrade was one of the three biggest and the most important institutions of higher education in Yugoslavia, with a crucial role for the state policy of creating trained professionals and a "new socialist intelligentsia". The development of the higher education system in Yugoslavia after WWII was determined, above all, by the Communist Party's seizure of power and the beginning of the construction of a new political and social-economic system.

During the first postwar years, the system of higher education was transformed and adjusted to the new goals and tasks, modeled on the Soviet pattern, shaped and imposed by the Party through the network of state and party organs and student mass organizations at universities and faculties. Through these bodies, the Party supervised the work and life of teachers and students, imposed political attitudes and Marxist ideology, and even strived to influence the teaching process itself. In Yugoslavia, the formation of the highly educated staff and a "new socialist intelligentsia" were ever-present basic tasks of the higher education system. ${ }^{1}$ The pressure of creating highly educated experts resulted in a sudden increase in the number of students in Yugoslavia. It jumped from less than 30,000 in 1945 to over 60,000 in 1948. At the University of Belgrade alone, the number of students in that same period increased from 15,000 to over $30,000 .^{2}$ They were all to become not only trained experts in their fields, but also committed representatives of the "new socialist intelligentsia". ${ }^{3}$

However, there were many obstacles in reaching these goals. The first was the animosity of a considerable part of the teaching staff and a significant segment of the student body toward the new regime and its ideology. In April 1947 among around 600

\footnotetext{
Bondžić, Beogradski univerzitet, pp. 137-170; Pervan, Tito and the Students, pp. 6-7.

Školstvo u FNRJ, p. 218.

Bondžić, Beogradski univerzitet, p. 298.
} 
teachers and teaching assistants, there were only 35 members of the Communist Party, mostly teaching assistants; ${ }^{4}$ in December 1947 among 25,000 students, there were around 2,000 communists; ${ }^{5}$ at the same time, it was estimated by the regime that a significant number of "political enemies" existed at all the departments. The regime tried to overcome this problem by intensive ideological and political work, by exerting pressure through propaganda, and by intermittent cleansing campaigns at the University, which led to the persecution and expulsion of political enemies among teachers and students. ${ }^{6}$

A new problem appeared in 1948 in the ranks of the Communist Party itself. In June 1948, the Resolution of the Cominform was published and the confrontation between Yugoslavia and Soviet Union (between Tito and Stalin) became public. It was an event of great international significance and after it, as John Gaddis asserts, "the communist world would never be the same again." 7 The Resolution of the Cominform and the conflict between Yugoslavia and the Soviet Union in 1948 caused a strong shock in the Communist Party of Yugoslavia and led to major changes in Yugoslav foreign and domestic policy, state, economy, society and culture. In foreign policy, the relations between Yugoslavia and Cominform countries deteriorated and the Yugoslav leadership gradually started cooperating with Western countries. The main consequence of the conflict in inner policy was a strong wave of repression against the supporters of the Cominform. It was only later, in the early 1950s, that a partial liberalization and changes in administration, economy and culture were implemented. ${ }^{8}$

The consequences of the conflict were also strongly felt at the University of Belgrade. It could be said that the effects of the Tito-Stalin split 1948 played out at three levels: control, persecution and expulsion of the teaching staff from the University, control, persecution, and expulsion of the students from the University, and long-term changes in the teaching process (curricula, syllabi, textbooks, literature, foreign language teaching, international scientific cooperation and exchange of students, etc.). ${ }^{9}$

4 Mitrović and Stanković, Zapisnici 1945 - 1948, p. 177.

5 Ibid., p. 227.

6 See more in: Bondžić, Beogradski univerzitet, pp. 238-263, 298-328; Bondžić, Univerzitet u socijalizmu, pp. 315321, 403-408. On the conditions at other universities in Southeast Europe see: Connely, Captive University, pp. 3-281; Najbar-Agičić, Kultura, znanost, ideologija, pp. 138-196; Connelly and Grüttner, Universities under Dictatorship, pp. 139-212, 245-295.

7 Gaddis, We Now Know, p. 48.

8 Ibid., pp. 48-49; Laqueur, Europe in Our Time, pp. 158-160; Lees, Keeping Tito Afloat, pp. 1-120; Cvetković, Između srpa i čekića, pp. 368-392; Previšić, Suđenja i kažnjavanja, pp. 197-214; Banac, Sa Staljinom, pp. 119251; Petranović, Istorija Jugoslavije, III, pp. 195-321; Dimić, Ideology and Culture, pp. 315-319; Gabrič, Preokret kulturno-politicke linije, pp. 101-106; etc.

9 The basis of this research is the documentation of the University administration in the Archives of Serbia, and the documentation of the state and party organs in the Archives of Yugoslavia and the Archives of Serbia (organs dealing with higher education and science and central committees of the Communist Party of Yugoslavia and Serbia).Unfortunately, the documentation of the secret police and the Serbian republican and federal state security authorities on this issue is still inaccessible. It is only possible to find some documents in the materials of the state and party organs and to use the published registry of people convicted because of the Cominform. Also, some relevant published sources, scientific literature and memoirs were useful for this research. 
The consequences of the Tito-Stalin split were not so severe for the university teachers because there weren't that many Party members among them. The older members of the Party from the University of Belgrade were far removed from communist theory and practice, so the split in the communist movement in 1948 did not influence them much. However, the Yugoslav-Soviet conflict did impact the careers and lives of several university teachers who were members or sympathizers of the Communist Party. They were all examined by Party authorities and asked to take a position and publicly declare their views about the Resolution of the Cominform. Also, pro-soviet attitudes expressed in classes and lectures were monitored and noted. According to the scarce archival documentation, eleven Resolution supporters who criticized the Yugoslav leadership were expelled from the Party and the University, and six of those were arrested and jailed at the Goli Otok camp. Mirko Marković and Marko Vranješević, teachers at the Faculty of Economics, Dušan Dohčević, professor at the Faculty of Law, Vladimir Spasojević, Milovan Bogdanović and Jovan Drakulić, teachers at the Faculty of Agriculture were expelled from the University and the Communist Party and jailed at the Goli Otok camp. Jelena Bogdanović, a teacher at the Faculty of Agriculture, Đorđe Pejić, Dimitrije Pejović, and Milena Janković, teachers at the Faculty of Economics, and Borislav Božović, a teacher at the Faculty of Medicine were only expelled from the University and the Party. ${ }^{10}$

Let's point out two interesting examples among the expelled professors of Belgrade University. Mirko Marković was born in 1906 in Montenegro. He became a member of the CPY in 1923. From 1925 to 1935 he lived and worked in the USSR where he obtained a doctorate in Economics in 1935. Then he was sent as a Comintern agent to work in the USA. From 1936 to 1939 he fought in the Spanish Civil War as a Commander of the American Brigade. From 1939 to the 1945 he lobbied for the interests of the CPY in the USA. In 1945 he returned to Yugoslavia and became an editor in the news agency and a colonel of the Yugoslav Army. In 1947 he was appointed associate professor of Political Economy at the Faculty of Economics in Belgrade. ${ }^{11}$ In September 1948 at a meeting of communists of the University of Belgrade, he declared himself in favor of the Cominform Resolution and against the Yugoslav leadership. He was immediately marked as a traitor. He was imprisoned and expelled from the CPY and from the University of Belgrade. ${ }^{12}$ From 1948 to the 1950 he was jailed in Belgrade and from 1950 to the 1954 he

10 Arhiv Srbije, Beogradski univerzitet, f. 56, Zapisnici sa sednica Univerzitetskog saveta, 10. I 1949, 5. IV 1949, 13. V 1949, 1. VII 1949, 5. V 1950; Arhiv Srbije, Medicinska velika škola, f. 29, 20. II 1950; Mihailović, et al., Zatočenici Golog otoka, pp. 118, 167,303, 436, 500; Bondžić, Beogradski univerzitet, pp. 258-261. It must be noted that some of the removed professors later returned to the University or continued their scientific careers at some other institution (B. Božović, M. Bogdanović, V. Spasojević, etc.).

11 Marković, Odabrani put, pp. 7-382.

12 Mitrović and Stanković, Zapisnici 1945 - 1948, pp. 45-51; Arhiv Srbije, Beogradski univerzitet, f. 56, Zapisnik sa sednice Univerzitetskog saveta, 10. I 1949; Arhiv Srbije, f. 6, Komitet za Univerzitet, Rešenje o suspenziji, 4. IX 1948; Mihailović, et al., Zatočenici Golog otoka, p. 303. 
was in the Goli Otok camp. In 1954 he was released but in 1958 he was imprisoned again and he spent two years in the Sveti Grgur camp. After his release, he dedicated himself to scientific work in economics and cybernetics. He died in 1988. In 1984 he wrote his memoirs. They were published under the title "The Chosen Path" in 1997. ${ }^{13}$

The second example is Marko Vranješević, a poet and a lecturer in the Russian language at the Faculty of Economics in Belgrade. He was born in 1903 in Bosnia. He graduated from the Faculty of Philosophy in Belgrade in 1929 and then he served as a Serbian language and literature teacher in high schools in Yugoslavia. During the Second World War, he participated in illegal activities of the National Liberation Movement in Belgrade. After the war he was one of the founders of the Association of Writers of Serbia and he worked as a teacher and head master in the Third High School in Belgrade. In 1947 he was appointed a lecturer in the Russian language at the Faculty of Economics in Belgrade. When the Resolution of the Cominform was launched in 1948, he was suspected as a "Russian spy" and he was arrested in May 1949 and then expelled from the University and the Association of Writers of Serbia. From 1949 to the 1951 he was at the Goli Otok camp and then he was released because he suffered a mental breakdown and was sent to hospital. He committed suicide in 1974. He wrote an autobiographical novel "The Shadow of the Goli Otok", published in 2004, three decades after his death. ${ }^{14}$

The situation of students attending the University of Belgrade was much more complicated. They were young and pretty inexperienced. Many were members of the Communist Party and some of them blindly believed the communist propaganda about the infallibility of the Soviet Union and Stalin. Some of them initially supported the Resolution of the Cominform during the summer of 1948, but a large number of them were "detected" and charged in the next few years. Their "culpability" and "sins" varied, as well as their punishment. Even though many students were on vacation during the summer of 1948, hearings began at the meetings of faculty party bodies and students were punished. Each student had to declare their views about the Cominform Resolution, and at the end of the session, a joint statement of support for the Yugoslav leadership was adopted. Students who supported the Cominform were marked as "enemies" and were quickly punished and expelled from the Party and the Faculty. Some of them were really ideologically close to the Soviet Union and Stalin, but many were only confused, afraid, inexperienced, hesitant to make a decision and didn't know what to do when they found themselves in this situation. ${ }^{15}$

13 Marković, Odabrani put, pp. 382-427. See also: Marković, Priča iz Petrove, pp. 335-341; Marković, Istina o Golom, pp. 113-114; Marić, Deca komunizma, p. 285; Banac, Sa Staljinom, p. 11; Cvetković, Između srpa i čekića, pp. 383-384; Popović, Marković Mirko, pp. 184-185.

14 Vranješević, Senka Golog otoka, pp. 297-350; Arhiv Srbije, Beogradski univerzitet, f. 56, Zapisnik sa sednice Univerzitetskog saveta, 1. VII 1949; Arhiv Srbije, Beogradski univerzitet, f. 84, Rešenje o udaljavanju sa Univerziteta, 6. VI 1949; Mihailović, et al., Zatočenici Golog otoka, p. 500.

15 Arhiv Srbije, CK SKS, Organizaciono-instruktorska uprava, f. 59; Mitrović and Stanković, Zapisnici 1948 1952, pp. 41, 43, 51-52; Mitrović, Rezolucija IB, pp. 246-249; Bondžić, Beogradski univerzitet, pp. 306-307. 
In September of 1948, the political situation at the University was unstable, especially at the Faculty of Mechanical Engineering and the Faculty of Agriculture. There appeared to be considerable support toward the attitudes expressed in the Resolution of the Cominform, as well as misunderstandings and uncertainty about the conflict. The Central Committee of the Communist Party of Serbia had to intervene: the Committee dismissed the Secretary of the University Committee (Danilo Purić replaced Vjera Kovačević) and then sent a special commission, whose task was to solve the problems and to calm down the political situation. The Commission consisted of members of the Central Committee of the Communist Party of Serbia, Dušan Petrović, Risto Antunović and Aleksandar Nikolić. Beside political action and "clarification" of the situation, the main method of the communists at the University was expelling "political enemies", supporters of Cominform and "waverers". By the end of October 1948 among 3,800 communists at the University of Belgrade, around 350 declared themselves supporters of the Cominform Resolution or hesitated to make a decision; 79 of them were expelled from the Communist Party and the University. By the end of 1948, 269 students who supported the Resolution of the Cominform in various ways were expelled from the University. Among them were some "waverers", but also candid supporters of the Cominform and Stalin, who were spreading Cominform propaganda, newspapers, leaflets, slogans and misinformation at the University. ${ }^{16}$

In the late 1940s and the early 1950s, a Party organization continued to control and monitor the political situation at the University in order to detect supporters of the $\mathrm{Co}^{-}$ minform and other "political enemies". All student members of the Party had to openly declare their views on the Resolution of the Cominform at the Party meetings. Suspicious and hesitant students were examined by Party authorities. The Party apparatus exercised control over political attitudes and everyday life and behavior of the all students at the University. Party organizations at the faculties and the University wrote detailed reports on the political situation, the attitudes of students towards the Cominform and the number of its supporters. Secret police officers and informants also monitored and recorded their observations in detailed reports. These carefully recorded data were sprinkled with denunciations (very often false) provided by colleagues, friends, roommates, etc. At some faculties organized groups of Cominform followers were detected. ${ }^{17}$

Various "gravities of sin" and "levels of guilt" were mentioned: support for the entire Resolution or just some parts of it; connections with outspoken supporters of the Resolution, concealing information about the activities of Cominform supporters, advocacy

16 Mitrović and Stanković, Zapisnici 1948 - 1952, pp. 54-56, 58-60, 125-131, 581-593; Mitrović, Rezolucija IB, pp. 249-250; Bondžić, Beogradski univerzitet, pp. 307-309.

17 Mitrović and Stanković, Zapisnici 1948 - 1952, pp. 128-133, 285-293, 449-452, 484-494, etc; Mitrović, Rezolucija IB, pp. 252-253; Bondžić, Beogradski univerzitet, pp. 309-311; Arhiv Jugoslavije, CK SKJ, Ideološka komisija, VIII, VII-5, k. 38, Izveštaj UDB-e, 10. XI 1951 (This report was published in: Bondžić, Izveštaj UDB-e, pp. 172-188). 
of the Cominform attitudes, spreading leaflets, booklets and newspapers, listening to radio stations from Cominform countries, writing hostile slogans, etc., glorification of Stalin and the Soviet Union, criticizing the Yugoslav Party and state leadership, complaints about the political situation in the country, objections to the foreign, domestic and economic policy of the Communist Party of Yugoslavia, jokes about Tito and other Yugoslav authorities, the expectation of a quick reconciliation with the Cominform, agitation against state policy, sabotage, defamation of the Yugoslav Party and state, hesitation, uncertainty, suspicion, confusion among students. All these were considered along with other political and ideological transgressions (lack of discipline, awareness, alertness, religiosity, but also immoral life, drinking, gambling, etc.). ${ }^{18}$

After July 1948, the party and state authorities reacted harshly in order to punish the supporters of the Cominform and reduce their influence at the University. Various penalties were introduced. Detected and hardened supporters of the Cominform were expelled from the Communist Party and from the Student's Youth Organization; all those were expelled from the faculties and the University, and consequently from student dormitories and all universities in the country. Depending on the degree of the offence, the supporters of the Cominform were arrested, jailed and interrogated about their views, activities and connections with other supporters of the Cominform. Finally, many were jailed in the Goli Otok camp (and also in the Sveti Grgur camp). This was called "rehabilitation" and "social volunteer work", and in fact, it was hard and inhumane torture. All these punishments were for the most part administrative measures, inflicted in the absence of trials or legal proceedings. The Goli Otok camp was called "The Company Mermer", and the prisoners were called "Mermeraši". This was an allusion to the hard work and stone processing that took place at the camp. ${ }^{19}$

The number of expelled and arrested students was growing. By the end of 1949, 495 members of the University Party organization were expelled, and more than half of them were subsequently jailed. ${ }^{20}$ It should be noted, though, that many expelled and jailed students were soon allowed to return and re-enroll at the faculties. They were under special control of the Party organization and the police. Some of them were readmitted to the Party, but many still worked in favor of the Cominform and were arrested again. Nonetheless, throughout the period, students were under a strong political, ideological and propagandistic influence so that the appearance of "incorrect views" would be prevented, the political situation clarified, and the already created "misconceptions" and misunderstandings corrected. One of the consequences was mass recruitment and

18 Arhiv Jugoslavije, CK SKJ, Ideološka komisija, VIII, VII-5, k. 38, Izveštaj UDB-e, 10. XI 1951; Arhiv Jugoslavije, CK SKJ, Kadrovska komisija, XIII-K. 64/5, Izjave studenata, IV-V 1952.

19 See more in: Previšić, Suđenja i kažnjavanja, pp. 198-203; Cvetković, Između srpa i čekića, pp. 376-381; Bondžić, Izveštaj UDB-e, pp. 172-174.

20 Mitrović and Stanković, Zapisnici 1948 - 1952, p. 285. 
engagement of students in the Communist Party. At the end of 1951, the number of communists at the University increased to almost 6,000 (members and candidates). ${ }^{21}$

It is important to mention that the accused and jailed students were often used for propagandistic purposes. In October 1949 in a Belgrade student newspaper, a letter from the students from "Mermer" was published. In it they, sincerely regretful, recognized their ideological "mistakes" and "misapprehensions", gave support to the Yugoslav Party and leadership, and promised to correct and revise their "wrong views". ${ }^{22}$

It's very difficult to give an estimate of the total number of students who supported the Cominform and who were punished for this. The official data changed from month to month. Consequently, we do not have a precise and total number. According to the report of the State Security Administration from November 1951, there were 25,377 students at the University of Belgrade; 5,798, or 22\%, were members of the Communist Party; at that time, 2,553 students were registered as being supportive of the Cominform, which was roughly $10 \%$ of all students and $44 \%$ of members of the CPY; among them there were 489 dangerous people who were under surveillance and 154 returnees from the Goli Otok camp. Therefore, $6 \%$ of the registered supporters spent some time in the Goli Otok camp. ${ }^{23}$ At the University itself ${ }^{24}$ there were 14,132 students, 2,636 of them or $18.6 \%$ were members of the Party, 1,128 students were registered as being supportive of the Cominform, which was $8 \%$ of all students and $44 \%$ of the members of the CPY; among them there were 171 people under surveillance and 50 returnees from the Goli Otok camp, or 4.4\% of the registered supporters. At the Medical College, there were 6,059 students and 1,533 of them, or 25.3\%, were members of the Party. 640 students were registered as being supportive of the Cominform, which was $10.6 \%$ of all students and $41.7 \%$ of the members of the CPY. Among them there were 137 people under surveillance and 50 returnees from the Goli Otok camp, or 7.8\% of registered supporters. At the Technical College, there were 5,284 students, 1,570 of them, or 29.7\%, were members of the Party, 692 students were registered as being supportive of the Cominform, which was $13.1 \%$ of all students and $44.1 \%$ of the members of the CPY.

21 Arhiv Jugoslavije, CK SKJ, Ideološka komisija, VIII, VII-5, k. 38, Izveštaj UDB-e, 10. XI 1951; Bondžić, Beogradski univerzitet, pp. 309-311; Mitrović, Rezolucija IB, pp. 252-253.

22 Narodni student, br. 21, 3. X 1949, pp. 3-4.

23 Arhiv Jugoslavije, CK SKJ, Ideološka komisija, VIII, VII-5, k. 38, Izveštaj UDB-e, 10. XI 1951; Bondžić, Izveštaj $U D B-e$, pp. 174-176.

24 It must be stressed that from 1948 to 1954 Belgrade University was divided into three parts: the University, consisting of seven faculties (Faculty of Economics, Faculty of Law, Faculty of Veterinary Medicine, Faculty of Philosophy, Faculty of Natural Sciences, Faculty of Agriculture, Faculty of Forestry), and Art Academies; the Medical College consisted of three faculties (Faculty of Medicine, Faculty of Pharmacy, Faculty of Dentistry); and the Technical College consisted of the Faculty of Mechanical engineering, the Faculty of Electrical engineering, the Faculty of Architecture, the Faculty of Civil Engineering, the Faculty of Technology, the Faculty of Mining and the Faculty of Geology. Bondžić, Beogradski univerzitet, pp. 114-116; Bondžić, Univerzitet u socijalizmu, pp. 86-87. 
Among them there were 181 people under surveillance and 54 returnees from the Goli Otok camp, or $7.8 \%$ of registered supporters. ${ }^{25}$

According to a later estimation produced by the Central Committee of the Communist Party of Serbia, by the mid-1950s 1,163 students supporters of the Cominform were expelled from the University of Belgrade; many were arrested and jailed, but most of them were allowed to return and continue their studies. ${ }^{26}$ In literature, we can find information that by 1953, 700 students who supported the Cominform were expelled from the University of Belgrade, and that 300 of them were arrested. ${ }^{27}$ Many of them were later allowed to return. Therefore, it can be concluded that all this time the state leadership was aware of the need to educate future professionals and offered punished students a chance to "correct" their mistakes, especially when the danger from the Soviets began to weaken.

Personal tragedies of professors and students were surely the most traumatic consequence of the 1948 split. However, there were less immediate, but very important consequences on the teaching process at the University of Belgrade, which went through a fundamental change. Before 1948, its curricula and syllabi were completely based on Soviet models; the teaching was mostly modelled after Soviet textbooks and literature; the achievements of Soviet science were excessively propagated and imposed; Russian was a mandatory course for all students; scientific cooperation and student exchange were directed solely at the Soviet Union and the countries of Eastern Europe. After 1948, in all these areas changes occurred at the University of Belgrade, and the orientation towards the East was abandoned. In the first few years after conflict, excessive emphasis on the achievements of Soviet science and its application in teaching was persecuted and interpreted as a show of support for the Cominform. Slowly, but of course not completely, the University started to turn to the West and gradually towards distant Third World countries. ${ }^{28}$ This academic expression of the new Yugoslav orientation may be the deepest repercussion of the Tito-Stalin Split, as it created a context in which generations of students were socialized.

25 Arhiv Jugoslavije, CK SKJ, Ideološka komisija, VIII, VII-5, k. 38, Izveštaj UDB-e, 10. XI 1951; Bondžić, Izveštaj $U D B-e$, pp. 174-176.

26 Arhiv Jugoslavije, CK SKJ, Kontrolno statutarna komisija, VII, K-1/18, Držanje kažnjenih po Informbirou, februar 1957.

27 Marković, Beograd između Istoka; Mitrović, Rezolucija IB, p. 253.

28 Bondžić, Hladni rat, pp. 353-370. 


\section{Sources and literature}

\section{Archival sources}

Arhiv Jugoslavije, Beograd, fond Centralni Komitet Saveza Komunista Jugoslavije (CK SKJ), Ideološka komisija, VIII, VII-5, k. 38, Izveštaj UDB-e o stanju na fakultetima Beogradskog univerziteta i velikih škola 1951. godine, 10. XI 1951.

Arhiv Jugoslavije, CK SKJ, Kadrovska komisija, XIII-K. 64/5, Izjave studenata Novinarske i diplomatske visoke škole u vezi držanja prema Rezoluciji Informbiroa, IV-V 1952.

Arhiv Jugoslavije, CK SKJ, Kontrolno statutarna komisija, VII, K-1/18, Držanje kažnjenih po Informbirou, februar 1957.

Arhiv Srbije, Beograd, fond Centralni Komitet Saveza komunista Srbije (CK SK), Organizaciono-instruktorska uprava.

Arhiv Srbije, Beograd, fond Beogradski univerzitet.

Arhiv Srbije, Beograd, fond Medicinska velika škola.

Arhiv Srbije, Beograd, fond Komitet za Univerzitet, velike škole i naučne ustanove NR Srbije.

\section{Published sources}

Bondžić, Dragomir, Izveštaj UDB-e o stanju na fakultetima Beogradskog univerziteta i velikih škola 1951. godine. Arbiv 1-2, 2003, pp. 172-188.

Mihailović, Dragoslav, Miroslav Jovanović, Goran Miloradović and Aleksej Timofejev, Zatočenici Golog otoka. Registar lica osuđivanih zbog Informbiroa. Dokument Uprave državne bezbednosti FNR Jugoslavije. Beograd: Arhiv Srbije, Institut za savremenu istoriju, 2016.

Mitrović, Momčilo and Đorđe Stanković, Zapisnici i izveštaji Univerzitetskog komiteta Komunističke partije Srbije, 1945 - 1948. Beograd: Centar za marksizam Univerziteta u Beogradu, 1985.

Mitrović, Momčilo and Đorđe Stanković, Zapisnici i izveštaji Univerzitetskog komiteta Komunističke partije Srbije, 1948 - 1952. Beograd: Centar za marksizam Univerziteta u Beogradu, 1988.

Školstvo u FNRJ 1945 - 1951. Beograd: Savet za nauku i kulturu Vlade FNRJ, 1952.

\section{Memoirs}

Marković, Mirko, Priča iz Petrove rupe. Koraci 5-6, 1988, pp. 335-341.

Marković, Mirko, Odabrani put (memoari). Podgorica: CID, 1997.

Vranješević, Marko, Senka Golog otoka. Beograd: Igor Vranješević, 2004.

\section{Newspaper}

Narodni student

\section{Literature}

Banac, Ivo, Sa Staljinom protiv Tita. Informbiroovski rascjepi u jugoslavenskom komunističkom pokretu. Zagreb: Globus, 1990. 
Bondžić, Dragomir, Beogradski univerzitet 1944 - 1952. Beograd: Institut za savremenu istoriju, 2004.

Bondžić, Dragomir, Beogradski univerzitet i Hladni rat 1945 - 1952. Velike sile i male države u Hladnom ratu 1945 - 1955. Slučaj Jugoslavije. Beograd: Arhiv Srbije i Crne Gore, 2005, pp. 353-370.

Bondžić, Dragomir, Univerzitet u socijalizmu. Visoko školstvo u Srbiji 1950 - 1960. Beograd: Institut za savremenu istoriju, 2010.

Connelly, John, Captive University. The Sovietization of East German, Czech, and Polish Higher Education 1945 - 1956. The University of North Carolina Press, 2000.

Connelly, John and Michael Grüttner (eds.), Universities under Dictatorship. The Pennsylvania University State University Press, 2005.

Cvetković, Srđan, Između srpa i čekića. Represija u Srbiji 1944 - 1953. Beograd: Institut za savremenu istoriju, 2006.

Dimić, Ljubodrag, Ideology and Culture in Yugoslavia (1945 - 1955). Velike sile i male države u Hladnom ratu 1945 - 1955. Slučaj Jugoslavije. Beograd: Arhiv Srbije i Crne Gore, 2005, pp. 303-319.

Gabrič, Aleš, Preokret kulturno-političke linije KPJ posle rezolucije Informbiroa. Istorija 20. veka 1, 2000, pp. 101-106.

Gaddis, J. Lewis, We Now Know. Rethinking Cold War History. Oxford University Press, 1997.

Laqueur, Walter, Europe in Our Time. A History 1945-1992. Penguin Books, 1992.

Lees, Lorain M., Keeping Tito Afloat. The United States, Yugoslavia and the Cold War. The Pensylvania State University Press, 1997.

Marić, Milomir, Deca komunizma. Beograd: NIRO Mladost, 1987.

Marković, Dragan, Istina o Golom otoku. Beograd: Narodna knjiga, 1987.

Marković, Predrag, Beograd između Istoka i Zapada 1948 - 1965. Beograd: Službeni list, 1996.

Mitrović, Momčilo, Rezolucija IB i studenti Beogradskog univerziteta 1948 -1952. Ideje i pokreti na Beogradskom univerzitetu od osnivanja do danas. Knjiga I. Beograd, 1989, pp. 245-253.

Najbar-Agičić, Magdalena, Kultura, znanost, ideologija, Prilozi istraživanju politike komunističkih vlasti u Hrvatskoj od 1945. do 1960. na polju kulture i znanosti. Zagreb: Matica Hrvatska, 2013.

Pervan, Ralph, Tito and the Students. The University and the University Student in Self-Managing Yugoslavia. University of Western Australia Press, 1978.

Petranović, Branko, Istorija Jugoslavije 1918 - 1988, III. Beograd: Nolit, 1988.

Popović, Branislav and Mirko Marković, Srpski biografski rečnik. Tom 6. Novi Sad: Matica srpska, 2014.

Previšić, Martin, Suđenja i kažnjavanja pristalica Rezolucije Informbiroa. Hereticus 1-2, 2013, pp. 197-214. 


\section{Summary}

\section{Dragomir Bondžić}

\section{The Repercussions of the Tito-Stalin Split in 1948 on the University of Belgrade}

The Resolution of the Cominform and the conflict between Yugoslavia and the Soviet Union in 1948 caused a great shock in the Communist Party of Yugoslavia and major changes in the Yugoslav state and society. The consequences of the conflict were also strongly felt at the University of Belgrade. The University of Belgrade was one of the three biggest and the most important higher education institutions in the country, with crucial importance for the state policy of educating future professionals and a "new socialist intelligentsia". That is why Party organs pervaded the University and controlled life, work, ideological and political views of the students and the teaching staff. The repercussions of the Tito-Stalin Split were expressed through a more active political control over the University, with participation of the secret police, and the removal of the Cominform supporters from the Party and the University. The first Cominform supporters among the teaching staff and students were detected and punished in the late summer of 1948. In the late 1940s and the early 1950s, the persecution of the Cominform supporters at the University continued. Some of them were arrested and taken to the Goli Otok camp. All the time there was constant ideological, political and propagandistic pressure on the teaching staff and the students, conducted by the Party organs, glorifying the policy of the Yugoslav leadership and attacking the Soviet Union and other countries of the Cominform. Finally, the repercussions of the conflict affected the teaching process through the contents of the curricula and syllabuses, lectures, textbooks, the teaching of the foreign languages, in international cooperation, orientation of scholarship policy, and student's daily life. 